\title{
Writing with Word Limits: A Review
}

\author{
Dadang Rhubido ${ }^{1}$ Kisyani Laksono ${ }^{1, *}$ Mintowati $^{2}$ Suhartono $^{3}$ Hespi Septiana ${ }^{4}$ Raras \\ Tyasnurita $^{5}$
}

\author{
1,2,3,4, Universitas Negeri Surabaya, Indonesia \\ 5 Institut Teknologi Sepuluh Nopember, Surabaya, Indonesia \\ ${ }^{*}$ Corresponding author. Email: kisyani@unesa.ac.id
}

\begin{abstract}
Writing is one form of literacy foundation. This study aims to describe the type of writing based on words limits (the number of words). The word limit is essential for writers. When you need to summarize a text with a limited number of words, your key points will be more straightforward. As a result, you will find insignificant sentences. The method is the descriptive method. The number of words in the essays covered starts from 50 words, 100 words, 500 words, 750 words. Based on the word count, there are several essays with various arguments. Papers with a word count of 750 can be developed for children to adults for fun, habituation, and learning. This paper suggests that creating a unique website to facilitate personal writing activities made by Indonesians and applicable to all languages, ranging from 50 words to writing books, will facilitae students' skills.
\end{abstract}

\section{Keywords: Writing, Word limit, Literacy foundation}

\section{INTRODUCTION}

Foundational literacies represent how students apply core skills to everyday tasks. These skills are the base upon which students need to build more advanced and equally important competencies and character qualities. This category consists of literacy (reading and writing), numeracy, scientific literacy, ICT literacy, financial literacy, and cultural and civic literacy [1].

Writing is one form of foundational literacy. Writing is one manifestation of literacy competence. Absorption of reading and one's knowledge will be expressed in writing. In writing, we can know someone's idea and focus on something. When someone writes, he will unconsciously use vocabulary close to his life and often uses it.

In writing, several limitations are used, starting from the theme or topic, the number of words, etc. In this study, the number of words that will be used is limited. Therefore, this study aims to describe the type of writing based on the number of words. This study is critical because the number of words is often neglected in Indonesian writing, even though a person will be more focused with a limit on the number of words. It is possible to use core words more than conjunctions. Writing based on the number of comments will increase the number of entries presented.

Concerning students, the content contained in student writing mainly contains things experienced by students. Thus they are close to everyday life-for example, activities at home, school activities, and social relationships in the family and community.

School-age children have different characteristics from younger children. He likes to play, move, socialize, wants to work in groups, and likes to feel or do things directly [2] [3]. The content of their writings is usually contextual. That is, the sentences in writing are very close to their lives.

This opinion aligns with Gardner [4] with his theory of multiple intelligences, especially verbal-linguistic intelligence. Verbal-linguistic intelligence can use languages including mother tongue and foreign language to express what is on the mind and understand other people. In addition, children who have more language intelligence than other children like to imitate sounds, language, read and write, learn and listen, read, write and discuss, listen effectively, understand, summarize, interpret and explain, and remember. What has been read, always trying to improve the use of language, creating new forms of language, working with writing, or liking spoken communication. 
Someone with more verbal-linguistic intelligence than others have an advantage in interpreting language. Another thing obtained from people who have this intelligence is the attitude in treating language and other things directly or indirectly related to language. It can be shown from the four language skills (listening, speaking, reading, and writing). In this case, vocabulary is the wealth of words owned by a person or a language [5]. Lema is a word or phrase entered in the dictionary beyond the definition or other explanation given in the entry [6]. Entries are often also referred to as dictionary entries. The wealth of a person's vocabulary and knowledge is generally considered a reflection of his intelligence or level of education [7]. The richness of the vocabulary will be reflected in the written vocabulary.

Vocabulary is an essential part of a language. The more vocabulary a person has, the more capable (capable) he is in communicating. Learning vocabulary as a provision of one's communication should be developed throughout life because language is constantly evolving. This study aims to describe writing based on word limits (the number of words). The word limit is essential for writers. When you need to summarize a text with a limited number of words, your key points will be more straightforward. As a result, you will find sentences that say nothing. Knowledge of vocabulary is essential for students. The amount of vocabulary in the students' writing will show how many words the students have mastered.

\section{METHODS}

In this case, the documentation method [8] is used from several websites holding writing competitions or websites accommodating writing activities. The discussion was carried out by commenting on some of these websites. Comments refer to various things that are presented on the web. In this case, many websites offer competitions or facilitate writing activities with a word limit, ranging from 50 words, 100 words, 200 words, 250 words, 500 words, 750 words, 1,000 words, etc.

Only four will be discussed in this case, namely those that refer to 50 words, 100 words, 500 words, and 750 words. This is done because the five limitations are pretty popular on the web.

\section{DISCUSSION}

There are several types of writing with word limits, including 50 words, 100 words, 250 words, 500 words, 750 words, 1,000 words, etc. In this discussion, only four types of writing will be presented, namely 50 words, 100 words, 500 words, and 750 words. Here is the discussion.

\subsection{Write 50 Words}

Writing a 50-word story is on several websites. What's interesting is at the web [9].
The initial greeting in the form of a challenge on the web was engaging "Can you write a story in just 50 words? We'll provide a prompt to get you started, but where the story goes from there.

The competition will be organized and administered by the Scottish Book Trust (the "Organisers"). In another section, it is written that "Reading for pleasure and writing creatively has a proven, consistent impact on mental health and wellbeing, and they have never been needed more than now."

This 50 -word writing challenge is intriguing. There is no age limit for the author. Apart from being a competition, writing 50 words can be practiced at any time or every day. However, keep in mind that the 50word limit implies that the writing will be dense with core words. The passion for writing for pleasure that underlies this idea is exciting and needs to be appreciated.

\subsection{Write 100 Words}

The first story held the 100 -word writing competition. The website can be checked on the web [10].

Like in the 50-word writing competition, this 100 word writing competition encourages us to write for fun and creativity. Further, it is hoped that the author can change lives. This program equips young people with the skills and confidence to tell their stories well and thrive in life and education. On their website, it says,"We're" working towards a society that encourages and supports young people from all backgrounds to write creatively for pleasure and agency. We believe there is dignity and power in telling your own story and that writing can transform lives. Our programs equip young people with the skills and confidence to tell their stories well and thrive in life and education.

Writing 100 -words is interesting. There is no age limit for the author, although, on the web, it is more aimed at young people. Apart from being a competition, writing 100 words can be practiced at any time or every day. However, keep in mind that the 100-word limit (as well as 50 words) implies that the text will be dense with core words. Nevertheless, the passion for writing for pleasure underlies this idea is exciting and needs to be appreciated.

\subsection{Write 500 Words}

The 500-word writing contest can be viewed on the web [11].

500 Words is the UK's most successful short storywriting competition for children between 5 and 13. Since the competition launched, 934,296 stories have been entered in the competition. It was founded back in 2011 after Chris Evans had a dream of getting all children excited about reading and writing, no matter their ability, experience, or background. So, the 500 Words initiative was created by Chris Evans and first launched in 2011. 
The competition created by Chris Evans also presents a more specific topic regarding black lives matter and is popular in the UK. The website can be viewed on the web [12].

These two competitions are for children aged 5-13 years divided into two groups: ages 5-9 and ages 10-13. The topics are written more precisely because they are related to black lives, which is still a hot issue. These two competitions are intended for children aged 5 to 13 years. They want to hear children's voices. For children with kindergarten or elementary school age, this competition encourages them to write. The open topic (general) for the first and second competitions also needs to be appreciated. In writing these 500 words, children can tell various things close to their lives or within reach of their imagination. Reading children's writings will help parents explore knowledge and open the door to communication with children.

\subsection{Write 750 Words}

A 750-word story writing competition was held in the UK in writers-online. The website can be viewed at this site [13]. On the web, there are also other writing competitions, even up to thousands of words. More specifically, the winners of the 750 -word contest can be seen at [14].

Writing 750 words is also popular on this site [15]. This site has been joined by 532,358 writers from all over the world. The motto is private, unfiltered, spontaneous, daily. It was written there that the site presented was. It says that the site offered is a new habit: Writing every day. What is presented is all online and private, not social media (blog, Facebook, etc.). Someone can try to write without worry because everything is personal, like a locked diary. The key is username and password. In that post, someone does not need to give a title, enable comments, or anything else. It is personal online writing in 750 words or the equivalent of three pages. Once it reaches the 750th word, it cannot be added anymore. This is good and awesome. Even in a day can also be written several writings; one article contains 750 words. Because 750 words are nothing to sneeze at, it is also nice to have an easy way to know how many words you have to go. This site, of course, tracks your word count at all times and lets you know when you have passed the blessed 750 marks. And it gives you a nice big screen to write on, automatically scrolls as you write (like a typewriter), and automatically saves your writing as you go.".

It was also mentioned that it was fun. Some points are earned when writing. The number of points will encourage us to write. It is fun to try to stay on streaks. The points are a way to play around with that. You can also see how others are doing points-wise if you are at all competitive that way. How I see it, points can motivate early on, and eventually, the joy of writing will kick in, and you will be writing without any external motivation at all." Writing every day 750 words will make you Learn about yourself in the process. It is even stated that. Free and fun writing is simple therapy and can improve the quality of life in many ways. Others will read no need to pay, no need to worry about the writing. It is personal, like a diary. Even in some ways, writing like this is considered better than meditation.

This website designed by Buster Benson [15] and his wife Kellianne helps keep it running smoothly. Their facilities are also provided through questions and answers via Twitter or Facebook.

How to register for this program is relatively easy. You can enter directly by submitting an email. There is a certificate if you write 750 words per day continuously. But, this website is designed for writing in English. If we write in Indonesian, there will be some adjustments to the writing of words in the program, but it does not matter. In this program, we are asked to write without editing, write, and write until the comments cannot be added anymore because it is 750 words.

Writing these 750 words is exciting and a pretty simple process. Therefore, writing these 750 words can be used for habituation and adopted for learning.

\section{CONCLUSION}

From some of these sites, it appears that several things can be observed. First, it starts from a small number of 50 words to 750 words. Second, even for the 750 words, a place for writing is provided every day. There is also a 1000 word writing competition, but it is not explicitly used. Writing with a word limit will make the writer use more main words (no conjunctions). In addition, the writing will be more focused and reveal important things that are cooled. As for habituation and enjoyment, an essay can use the 750-word model. In addition to habituation and fun, writing 750 words can also be used for learning. Hopefully, in the future, there will be a unique website to facilitate personal writing activities made by Indonesians and applicable to all languages, ranging from 50 words to writing books (individual or you to you).

\section{ACKNOWLEDGMENTS}

This research was funded under the PKM grant scheme from the Faculty of Languages and Arts, Universitas Negeri Surabaya. The authors are grateful to Univeristas Negeri Surabaya for funding the PKM entitled Training Learning Literature Written For Khadijah 3 Surabaya Elementary School Teachers.

\section{REFERENCES}

[1] WEForum, "The skills needed in the 21st century." [Online], Available: 
https://widgets.weforum.org/nve-

2015/chapter1.html.

[2] Desmita, Psikologi Perkembangan Peserta Didik, Bandung: Rosda Karya, 2009.

[3] L. Nuryanti, Psikologi Anak, Jakarta: Indeks, 2009.

[4] H. E. Gardner, Intelligence reframed: Multiple intelligences for the 21st century, Hachette UK, 2000.

[5] K. Laksono, F. Inayatillah, M. Ms, and M. Ms, "The Development of Vocabulary in Bahasa Indonesia Textbook for Senior High School," 2018, [Online]. Available:

file:///Users/rarastyasnurita/Downloads/25903316. pdf.

[6] F. Inayatillah, Kisyani, Mintowati, and Mukhzamilah, "Entry application software to identify the development of reading and writing vocabulary," in Journal of Physics: Conference Series, 2019, vol. 1339, no. 1, doi: 10.1088/17426596/1339/1/012117.

[7] K. Pahl and J. Rowsell, "The new literacy studies and teaching literacy: Where we were and where we are going," 2012.

[8] L. J. Moleong, Metodologi penelitian, Bandung: Penerbit Remaja Rosdakarya, 2004.

[9] Scottishbooktrust, "500 Word Fiction," 2021. https://www.scottishbooktrust.com/50-wordfiction.

[10] Firststory, "First Story," 2021. https://firststory.org.uk/about/.

[11] BBC, "About 500 Words," [Online], Available: https://www.bbc.co.uk/programmes/articles/50pnq LfDywb9CFxjNvth510/about-500-words.

[12] V. Radio, "500 Words Black Lives Matter." https://500words.me/black-lives-matter/.

[13] W. Online, "Writers Online." [Online], Available: https://www.writers-online.co.uk/.

[14] Writers online, "Writers Online," 2021. [Online], Available: https://www.writersonline.co.uk/writing-competitions/750-wordcompetition-2021/.

[15] B. Benson, "750 Words," 2021. [Online], Available: https://750words.com/ 